\title{
Nectar and oleiferous trichomes as floral attractants in Bulbophyllum saltatorium Lindl. (Orchidaceae)
}

\author{
Małgorzata Stpiczyńska $^{1}$ (D) $\cdot$ Bartosz J. Plachno ${ }^{2} \cdot$ Kevin L. Davies $^{3}$
}

Received: 28 March 2017 / Accepted: 6 September 2017 / Published online: 24 September 2017

(C) The Author(s) 2017. This article is an open access publication

\begin{abstract}
Although many Orchidaceae have deceit flowers that produce no reward, the most common reward, when present, is nectar. Bulbophyllum, however, is unusual in that the labellar secretions of most species investigated to date lack sugars, and, therefore, cannot be considered true nectar. The African species Bulbophyllum saltatorium is an exception in that it produces not only nectar but also possesses specialized, capitate oleiferous trichomes. The nectary of $B$. saltatorium is borne on the labellum and is represented by a deep, narrow, median longitudinal groove, having a small aperture, and flanked by trichomes. Isodiametric epidermal cells lining this groove secrete nectar which collects both in the groove and on the surface of the labellum. As well as a nectary, the labellum of B. saltatorium also bears three types of unicellular trichomes: the longest trichomes are borne distally and abaxially; the marginal ones form a rim around the entire labellum, and finally, massive, capitate trichomes occur proximally and adaxially. These are oleiferous, containing large quantities of oil which might function as precursors of volatile components of fragrance or provide a food-reward. To the best of our knowledge, this is the first time for such oleiferous trichomes to be described for Bulbophyllum. Therefore, apart from their color and markings, flowers of this species are able
\end{abstract}

Handling Editor: Hanns H. Kassemeyer

Małgorzata Stpiczyńska

stpiczynska_mal@biol.uw.edu.pl

1 Faculty of Biology, University of Warsaw, Botanic Garden Al. Ujazdowskie 4, 00-478 Warsaw, Poland

2 Department of Plant Cytology and Embryology, Jagiellonian University in Kraków, 9 Gronostajowa St., 30-387 Kraków, Poland

3 School of Earth and Ocean Sciences, Cardiff University, Main Building, Park Place, Cardiff CF10 3AT, UK to attract pollinators in at least two, possibly three ways: foodreward in the form of nectar; fragrance; and possibly foodrewards in the form of food-hairs.

Keywords African Bulbophyllum · Cell wall ingrowths . Flower morphology $\cdot$ Labellar micromorphology $\cdot$ Nectaries . Oleiferous trichomes · Section Ptiloglossum - Ultrastructure

\section{Introduction}

Considered to be the largest orchid genus (Pridgeon et al. 2014), Bulbophyllum Thouars comprises some 2200 species occurring throughout tropical Africa, the Comoros, Madagascar, the Seychelles, Reunion and Mauritius, Asia, the Philippines, New Guinea, the tropical Pacific islands, Australia, New Zealand and the Neotropics, the main centers of distribution being Madagascar and New Guinea (Pridgeon et al. 2014). It is entomophilous, with morphologically diverse and intricate flowers displaying some of the most varied and complex pollination strategies to be found amongst orchids, and is pollinated by a wide range of insects, most notably, Coleoptera, Hymenoptera (mainly in Africa), such as wasps and bees, including stingless bees and ctenuchid wasps (Johansson 1974 - cited in van der Cingel 2001; Dressler 1990, 1993; van der Cingel 2001; Chen and Gao 2011), but mainly Diptera, including fruit-flies, blowflies, flesh flies and signal flies or Platystomatidae (van der Cingel 2001; Tan and Nishida 2000, 2005; Tan et al. 2002; Humeau et al. 2011; Ong 2011; Ong et al. 2011 and references therein; Ong and Tan 2011, 2012; Liu et al. 2010; Stewart et al. 2014). As such, one would expect this genus to be a potentially rich source of new information about plant adaptation (Gravendeel et al. 2004; Fischer et al. 2007). 
The rewardless condition is frequent amongst orchids (Jersáková et al. 2006), but when floral rewards are present, they mainly occur as nectar (Dressler 1990, 1993; Davies and Stpiczyńska 2008). True nectar (i.e. a sugar-rich, floral secretion attractive to pollinators) is uncommon in Bulbophyllum (personal observation). Indeed, by now, almost a century has passed since Pohl (1935) reported the occurrence of a sugarand oil-rich secretion at the base of the labellum and adjacent flower parts of Bulbophyllum lobbii Lindl. (sect. Sestochilos (Breda) Benth. \& Hook.f.) and Bulbophyllum macranthum Lindl. (sect. Stenochilus J.J.Sm.), yet since then, relatively few studies have considered food-rewards in Bulbophyllum. Field studies have reported food-rewards in a number of species such as Bulbophyllum alticola Schltr. (sect. Hapalochilus Schltr.), Bulbophyllum auratum (Lindl.) Rchb.f. (sect. Recurvae Benth. \& Hook. f.), B. lobbii and B. macranthum (Pohl 1935; Jongejan 1994; van der Cingel 2001), but anatomical studies of the flower with ultrastructural and histochemical investigations of the secretory process are rare, in particular for African species. To date, the floral anatomy of representatives of the Neotropical sections Didactyle (Lindl.) Cogn., Napellii Rchb.f. and Micranthae Barb. Rodr. (Nunes et al. 2014, 2015, 2017) has been studied at SEM and light microscopy level, including histochemical tests, and combined histochemical, micromorphological and ultrastructural studies have been performed on members of Asian sections that include Cirrhopetaloides Garay, Hamer \& Siegerist, Cirrhopetalum (Lindl.) Rchb.f. (Kowalkowska et al. 2015, 2016) and Racemosae Benth. \& Hook.f. (Davies and Stpiczyńska 2014; Stpiczyńska and Davies 2016), and on African sections Megaclinium G. A. Fischer \& J. J. Verm., Oreonastes G. A. Fischer \& J. J. Verm. and Ptiloglossum Lindl. (Stpiczyńska et al. 2015). Of these, histochemistry revealed that lipids were abundant in the labellar cells of most species, except for those of sect. Racemosae, where the secretion consisted predominantly of protein-laden mucilage (Davies and Stpiczyńska 2014; Stpiczyńska and Davies 2016). In most cases, these secretions were produced by palisade-like epidermal cells lining the median, longitudinal labellar groove. Traditionally, but misleadingly (considering they had not been shown to produce a sugary liquid), these grooves have often been referred to as nectaries. One exception, however, is Bulbophyllum schinzianum Kraenzl. (sect. Ptiloglossum), whose floral secretion, on subjecting to refractometry, gave a total sugar value of $61.7 \%$ (Stpiczyńska et al. 2015), strongly indicating, given that it also produces fragrance, that it is not pseudocopulatory, as had previously been proposed (Jongejan 1994; van der Cingel 2001). Indeed, based on the form and depth of the labellar groove and the presence of fragrance and nectar, it is possible that this species is pollinated by Hymenoptera (Stpiczyńska et al. 2015), especially as these insects have been reported to visit such flowers (Johansson 1974). Conversely, Stewart et al. (2014) reported that flowers of B. schinzianum var. schinzianum are also visited by flies, and therefore, further field studies are required.

Here, we extend our investigations to a further African species, namely Bulbophyllum saltatorium Lindl. The hairy flowers of this species, in some respects, resemble those of B. schinzianum, and both are members of the same section, namely, Ptiloglossum. Preliminary studies, however, indicated that both species differ in the floral rewards that they produce. The aim of our present paper, therefore, is to investigate the micromorphology and histochemistry of the hirsute labellum of $B$. saltatorium, to check for the presence of floral foodrewards and to describe the tissues involved in their production.

\section{Material and methods}

The plants of Bulbophyllum saltatorium used in this study were cultivated at the Botanic Garden of the Jagiellonian University in Kraków (living collections accession number $\mathrm{O} / 2014 / 1185$ ). Voucher material was deposited at the Herbarium of Jagiellonian University in Kraków (accession number KRA 464137).

\section{Microscopy investigations}

In the present study, we employed microscopy techniques described in detail by Stpiczyńska and Davies (2016, and references therein). In order to determine the presence of secretory tissues and surface secretions, intact flowers were immersed in solutions of the following stains: Sudan III for lipids; ruthenium red (RR) for mucilage; and Coomassie Brilliant Blue R 250 (CBB) for proteins. The stained parts of flowers were examined by means of a Nikon SZM1000 stereoscopic microscope. Sections of secretory tissues from proximal and median parts of the labellum were subsequently examined using bright field and fluorescence light microscopy (LM). Semi-thin sections were stained using methylene blue/azure II (MB/AII) for general histology and the periodic acid-Schiff reaction (PAS) for insoluble polysaccharides. Hand-cut sections of both fresh and fixed material were stained with Sudan III, CBB, Lugol's iodine solution (IKI), and RR for lipids, proteins, starch and mucilage, respectively. Furthermore, an epifluorescence microscope equipped with Prior 200 W lamp (Prior Scientific Instruments Ltd.) and UV-2B filter was employed for the investigation of cell walls, and in particular, the cuticle, in unstained material fixed in $70 \%$ ethanol, since observations of cells located deep in the labellar groove were difficult using SEM. The structure of the cuticle was further investigated by staining paradermal sections with auramine O (Ruzin 1999) and viewing them using blue light (FITC-Nikon cube filter). 
For scanning electron microscopy (SEM), parts of the labellum were dehydrated and subjected to critical-point drying using liquid $\mathrm{CO}_{2}$. They were then sputter-coated with gold and examined using a Hitachi S-4700 scanning electron microscope (Hitachi, Tokyo, Japan), at an accelerating voltage of $20 \mathrm{kV}$.

Pieces of labellum from both proximal and median parts were fixed in $2.5 \%(v / v)$ glutaraldehyde $/ 4 \%(v / v)$ formaldehyde in $0.1 \mathrm{M}$ sodium cacodylate buffer ( $\mathrm{pH} 7.0$ ), washed in the same buffer and post-fixed in 1.5\% (w/v) osmium tetroxide solution. They were dehydrated using a graded acetone series and embedded by means of a Spurr Embedding Kit (Sigma). Following polymerization, sections were cut at $70 \mathrm{~nm}$ for transmission electron microscopy (TEM) using a LKB ultramicrotome, stained with uranyl acetate and lead citrate (Reynolds 1963), and examined using a JEM 1400 (JEOL Co., Japan, 2008) transmission electron microscope, at an accelerating voltage of $80 \mathrm{kV}$.

Micrometry and photomicrography were accomplished using NIS-Elements BR software and DS-Fil digital camera (Nikon, Japan), and a high-resolution digital camera (CCD MORADA, SiS-Olympus, Germany) for LM and TEM images, respectively.

\section{Results}

Bulbophyllum saltatorium flowers are borne on a simple raceme, and each is subtended by a prominent papery bract (Fig. 1a). The bases of the sepals and petals (including the labellum) are more darkly pigmented than the remaining parts, and the flowers have a faint, sweet fragrance.

The labellum is densely hirsute (Fig. 1a-d). The distribution and surface features of the various kinds of labellar trichomes are shown in the SEM images (Fig. 2a-f). The longest trichomes, which measure as much as $3.5 \mathrm{~mm}$ in length $\times 18 \mu \mathrm{m}$ in diameter, are present on the distal, abaxial surface of the labellum (Figs. 1a, b and 2a). These trichomes are unicellular with cellulosic cell walls and an irregularly or helically sculptured cuticle (Fig. 2d). In the parietal cytoplasm, small plastids occur, and the vacuoles contain anthocyanins. These trichomes do not contain any storage materials.

Marginal trichomes form a dense border or rim around the labellum. They are shorter and narrower than those described previously, measuring only some $300 \mu \mathrm{m}$ in length $\times 10 \mu \mathrm{m}$ in diameter, and have acute apices (Figs. 1c and 2a, c, e). The cuticle overlying the cellulosic cell walls is smooth and of regular thickness. Like the long trichomes, these hairs do not accumulate any substantial storage materials. Adaxially, on the proximal part of the labellum, and especially near the two proximal labellar projections, massive capitate trichomes are present, measuring $450 \mu \mathrm{m}$ in length $\times 30 \mu \mathrm{m}$ in diameter, with capitate tips (Figs. 1d and 2e, f). The cuticle overlying the trichome is irregularly striate, with horizontally orientated striae located close to the apex, which is smooth (Fig. 2f) and, as viewed using SEM, lacks pores and cracks. These trichomes contain large lipid droplets (Fig. 1c, d). Similar lipid droplets also occur in the epidermal and subepidermal parenchyma cells (Fig. 1e-h). Neither the intravacuolar contents of the three types of trichome mentioned previously, nor those of the adaxial epidermal cells displayed specific autofluorescence when exposed to UV light.

The median part of the labellum was coated with sweettasting nectar. Under SEM, residues of nectar were visible as a reticulum, or as a fine fibrous weft overlying short trichomes and conical papillae distributed alongside the median, deep, longitudinal groove, and this material was particularly abundant upon the callus (Fig. 2g, h). Marginal parts of the labellum were glabrous and lacked nectar. Transverse sections of the labellum revealed that the median, longitudinal groove of the labellum was lined with epidermal cells of mean dimensions $18.7 \times 12.5 \mu \mathrm{m}$. These were not palisade-like, as in many other Bulbophyllum spp., but each contained a large nucleus and dense cytoplasm (Fig. 3a). The subepidermal parenchyma comprised several layers of compactly arranged, small isodiametric cells. Adjacent epidermal cells (located more laterally) were larger, having mean dimensions of $23.3 \times 30.5 \mu \mathrm{m}$, and contained thin parietal cytoplasm and a large vacuole. Deeply located parenchyma cells were large, with extensive intercellular spaces, and resembled spongy mesophyll (Fig. 3b). Occasionally, large idioblasts with raphides also occur in this region. Generally, starch was lacking from epidermal cells (those lining the median groove, as well as those that are more marginally located), but was present in parenchyma (Fig. 3b, c), particularly in the vicinity of vascular bundles.

Sections of the labellum through the median longitudinal groove region tested with RR (Fig. 3d), and Sudan III, revealed that mucilage and lipids, respectively, were absent from the surface secretion. Testing with CBB also showed that the surface secretion lacked proteins. Staining sections with auramine $\mathrm{O}$ (Fig. 3a) and observations made using UV light (Fig. 3f) revealed an intact cuticle with no visible pores or cracks. However, cell walls stained following treatment with $\mathrm{RR}$, and the dense cytoplasm of secretory cells stained with CBB.

Vacuolar contents of subepidermal parenchyma autofluoresced light blue when subjected to UV light (Fig. $3 \mathrm{f}$ ), whereas staining with auramine $\mathrm{O}$ revealed the presence of minute lipid droplets (probably plastoglobuli) in epidermal and subepidermal parenchyma cells.

Transmission electron microscopy of adaxial epidermal cells from the proximal part of the labellum revealed a prominent, centrally located nucleus and dense cytoplasm containing a relatively large vacuole (Fig. 4a). Lipid completely filled both this and numerous smaller vacuoles, whereas some small 
Fig. 1 Gross floral morphology and labellar anatomy, LM. a

Habit of flower, scale bar $=1 \mathrm{~mm}$. b Whole labellum stained with Sudan III. The position of nectary groove (visible through the abaxial surface) is marked by an arrow, scale bar $=1 \mathrm{~mm}$. c Short, pointed trichomes and bases of massive trichomes containing lipid droplets (arrows) following staining with Sudan III, scale bar $=50 \mu \mathrm{m}$. d Massive capitate trichomes containing lipid droplets stained with Sudan III, scale bar $=20 \mu \mathrm{m}$. e A similar preparation showing the presence of lipids in the epidermal and parenchyma cells of the proximal part of the labellum, scale bar $=50 \mu \mathrm{m}$. f Section stained with $\mathrm{MB} / \mathrm{AB}$ showing large, gray lipid droplets in epidermal cells, scale bar $=10 \mu \mathrm{m}$. g Sparse, minute starch grains (PAS) and thin cellulosic cell walls occur in the lipid-secreting region. Note gray lipid droplets, scale bar $=20 \mu \mathrm{m}$. h Paradermal section stained with auramine $\mathrm{O}$. Note the abundant, fluorescent green lipid droplets, scale bar $=10 \mu \mathrm{m} . R$ raphides
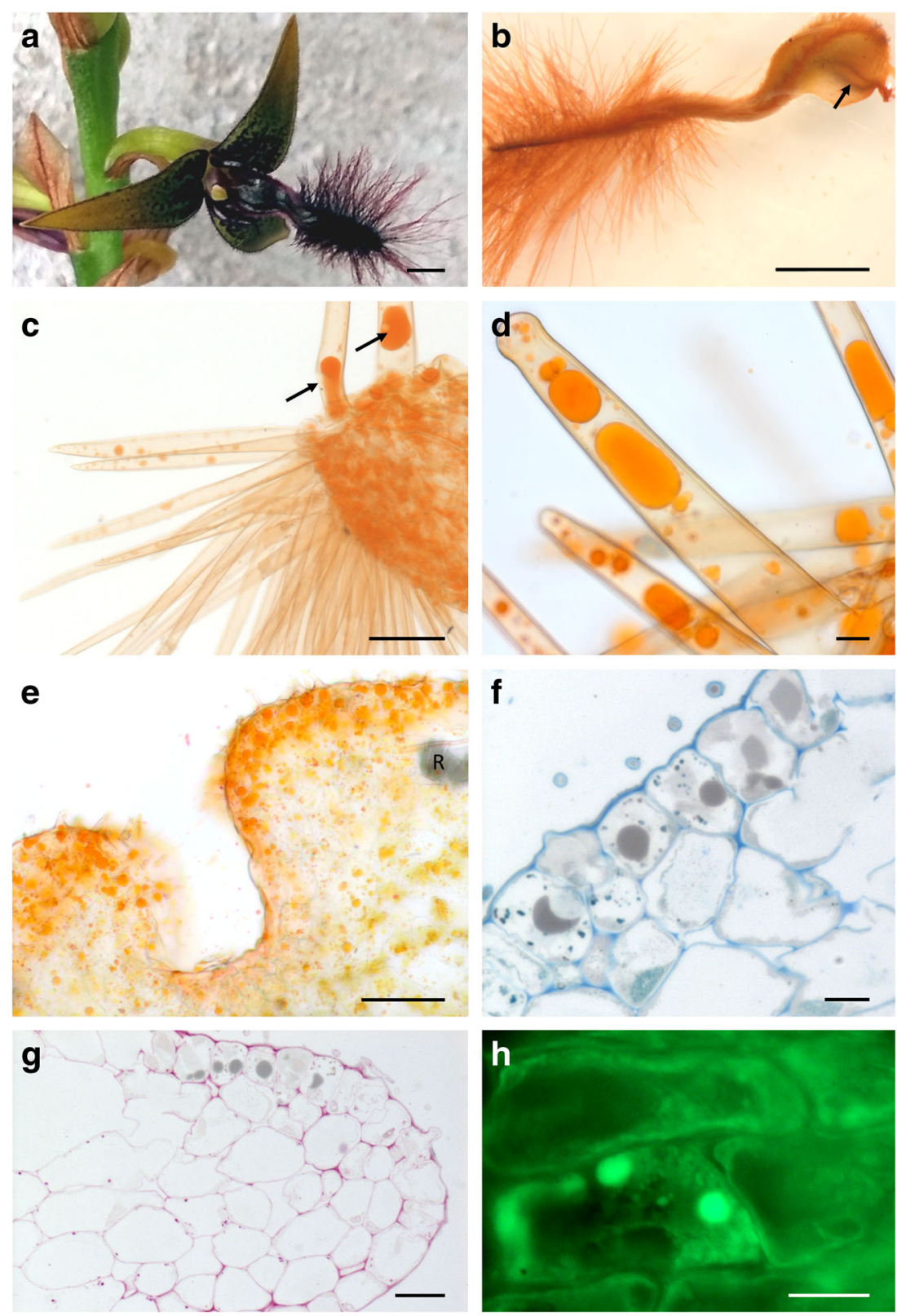

vacuoles and vesicles scattered throughout the cytoplasm contained electron-dense material (Fig. $4 \mathrm{a}-\mathrm{c}$ ). The cytoplasm contained abundant smooth (SER) and rough endoplasmic reticulum (RER), and close examination showed that both SER and RER produced small vesicles by budding. Dictyosomes were also frequently seen. The numerous mitochondria were mainly located in the parietal cytoplasm (Fig. $4 a, d)$. Plastids were rarely observed, but when present, they contained an electron-dense stroma, few internal tubules and plastoglobuli, but starch was absent (Fig. 4b-e). By contrast, plastids in the subepidermal parenchyma contained small starch grains (Fig. 4f). Plasmodesmata connected adjoining epidermal and subepidermal cells (Fig. 4b, f). The plasmalemma was often very convoluted, resulting in the formation of an extensive periplasmic space. A distinctive feature of epidermal cells, and to a lesser degree subepidermal parenchyma cells, was the presence of cell wall ingrowths (Fig. 4a, b) distributed fairly regularly along the length of the cell walls.

These were also present in nectar-secreting cells lining the median groove (Fig. 5a-f). Nectary cells had thick, outer cellulosic walls and a thin, smooth cuticle without visible microchannels. The surface secretion that collected on the surface of the cell wall (Fig. 5a, b) was often fibrous or weft-like, but sometimes it had a more solid appearance. As in lipidcontaining cells, the plasmalemma was convoluted (Fig. 5a$\mathrm{f}$ ), and the periplasmic space formed contained many secretory vesicles (Fig. 5b-f). Furthermore, secretory vesicles of various sizes gathered in the parietal cytoplasm, alongside the 
Fig. 2 Micromorphology of the labellum, SEM. a Part of labellum showing median longitudinal groove and hairy callus. One of two visible basal projections marked by an arrow. Also note the border of short trichomes - black asterisks, and the long, marginal trichomes - white asterisks, scale bar $=500 \mu \mathrm{m}$. b Proximal part of labellum with two projections (arrows), scale bar $=150 \mu \mathrm{m}$. c Short trichomes (black asterisk) and smooth cuticle, and long marginal trichomes (white asterisk) of the labellum, scale bar $=60 \mu \mathrm{m}$. d Detail of the striate cuticle of long trichomes from apical part of the labellum. Note the helical arrangement of cuticular striae, scale bar $=20 \mu \mathrm{m}$. e Glabrous proximal, adaxial surface of labellum with rim of massive, capitate, oleiferous trichomes (arrows). Marginal rim of short trichomes marked by asterisk, scale bar $=200 \mu \mathrm{m}$. $\mathbf{f}$ Detail of swollen apex of massive, capitate hair, scale bar $=10 \mu \mathrm{m} . \mathbf{g}$ Median groove and hairy callus coated with nectar (asterisks), scale bar $=500 \mu \mathrm{m}$. h Reticulum of nectar residues between callus trichomes, scale bar $=15 \mu \mathrm{m}$
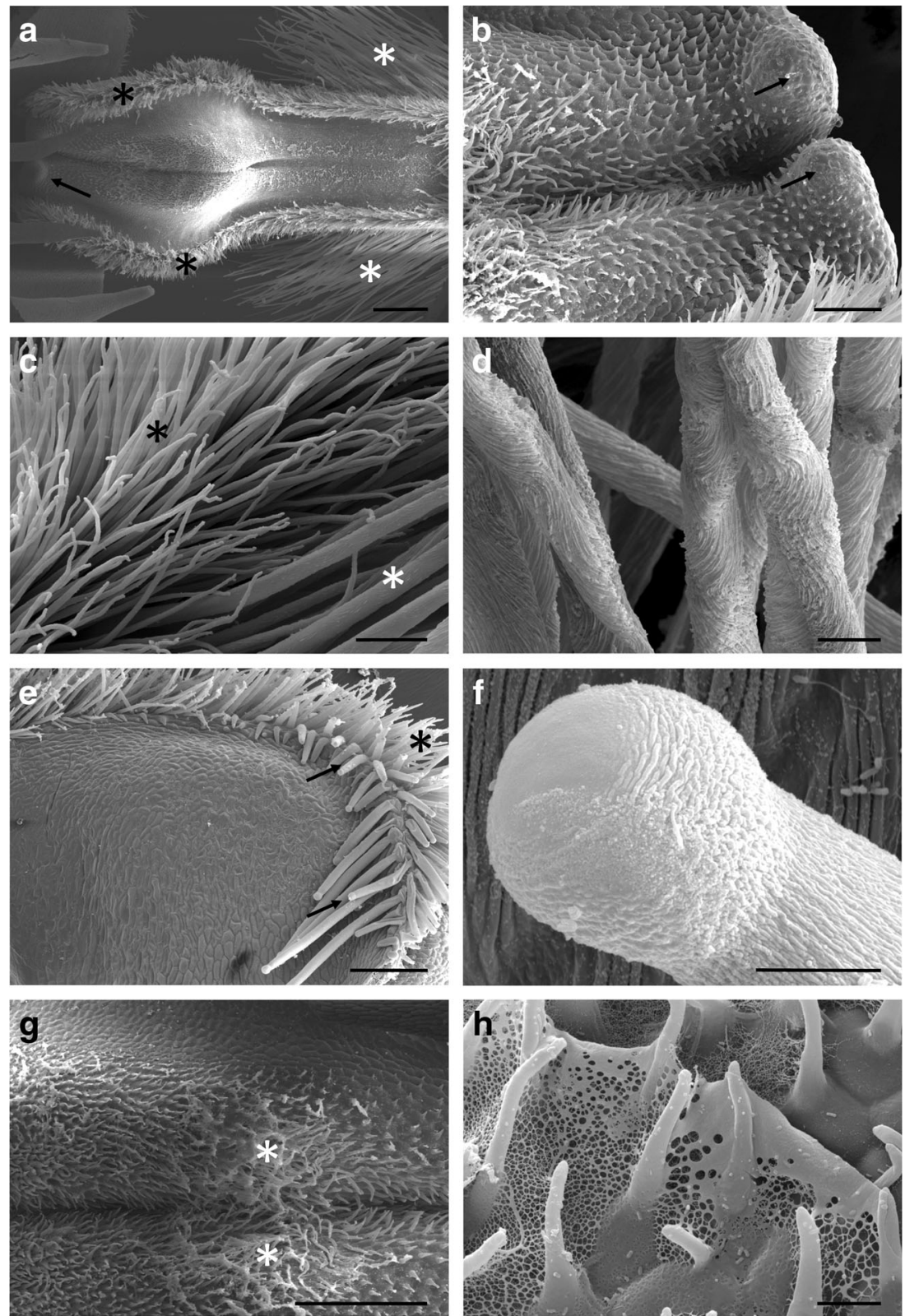

plasmalemma, and fused with the latter (Fig. 5d-f). Abundant dictyosomes were present in the parietal cytoplasm, together with profiles of SER, RER and mitochondria, as well as small, multivesicular bodies (MVBs) (Fig. 5a). Vacuoles here were small and electron-translucent or contained flocculent material (Fig. 5a, c). They gathered predominantly in the apical parts of papillae. Occasionally, small vacuoles containing lipid were also observed. Vacuoles present in the subepidermal parenchyma were large and predominantly electron-translucent, or they contained membranous or fibrous material. Epidermal and subepidermal cells were interconnected via numerous plasmodesmata (Fig. 5a-c), the latter being particularly densely distributed on the adjoining walls of mesophyll-like parenchyma cells.

\section{Discussion}

Of the species of Bulbophyllum studied to date, the median labellar groove of $B$. saltatorium most closely resembles that of $B$. schinzianum in that it is relatively deep, with a narrow aperture, and densely flanked by unicellular papillae and trichomes (Stpiczyńska et al. 2015). Since the cells lining the groove secrete a sugary liquid, like that of $B$. schinzianum, it can also be referred to as a nectary. Like the nectar of $B$. schinzianum, that of $B$. saltatorium also lacks lipid, protein and mucilage, as confirmed by histochemical tests, unlike that of Asian B. lobbii, which is reported also to contain oil (Porsch 1905; Stpiczyńska et al. unpublished). 
Fig. 3 Nectar secreting region of the labellum, LM. a

Section showing secretory epidermis lining the median groove and underlying subepidermal parenchyma (MB/ $\mathrm{AB}$ ), secretory residues marked by an asterisk, scale bar $=20 \mu \mathrm{m}$. b Epidermis and subepidermal parenchyma in the marginal part of the labellum. Starch is present in the mesophyll-like parenchyma cells (PAS), scale bar $=20 \mu \mathrm{m}$. c Section (as in a) stained with PAS reveals the absence of starch, but relatively thick cellulosic tangential cell walls stain with this reagent, scale bar $=20 \mu \mathrm{m}$. d Staining with RR reveals the absence of mucilage from idioblasts and the surface secretion, scale bar $=20 \mu \mathrm{m}$. e Staining with auramine $\mathrm{O}$ reveals an intact cuticle overlying the nectary, scale bar $=10 \mu \mathrm{m}$. f Section of callus region viewed with UV. Note autofluorescence of vacuolar contents of subepidermal cells, scale bar $=20 \mu \mathrm{m}$. Id idioblast
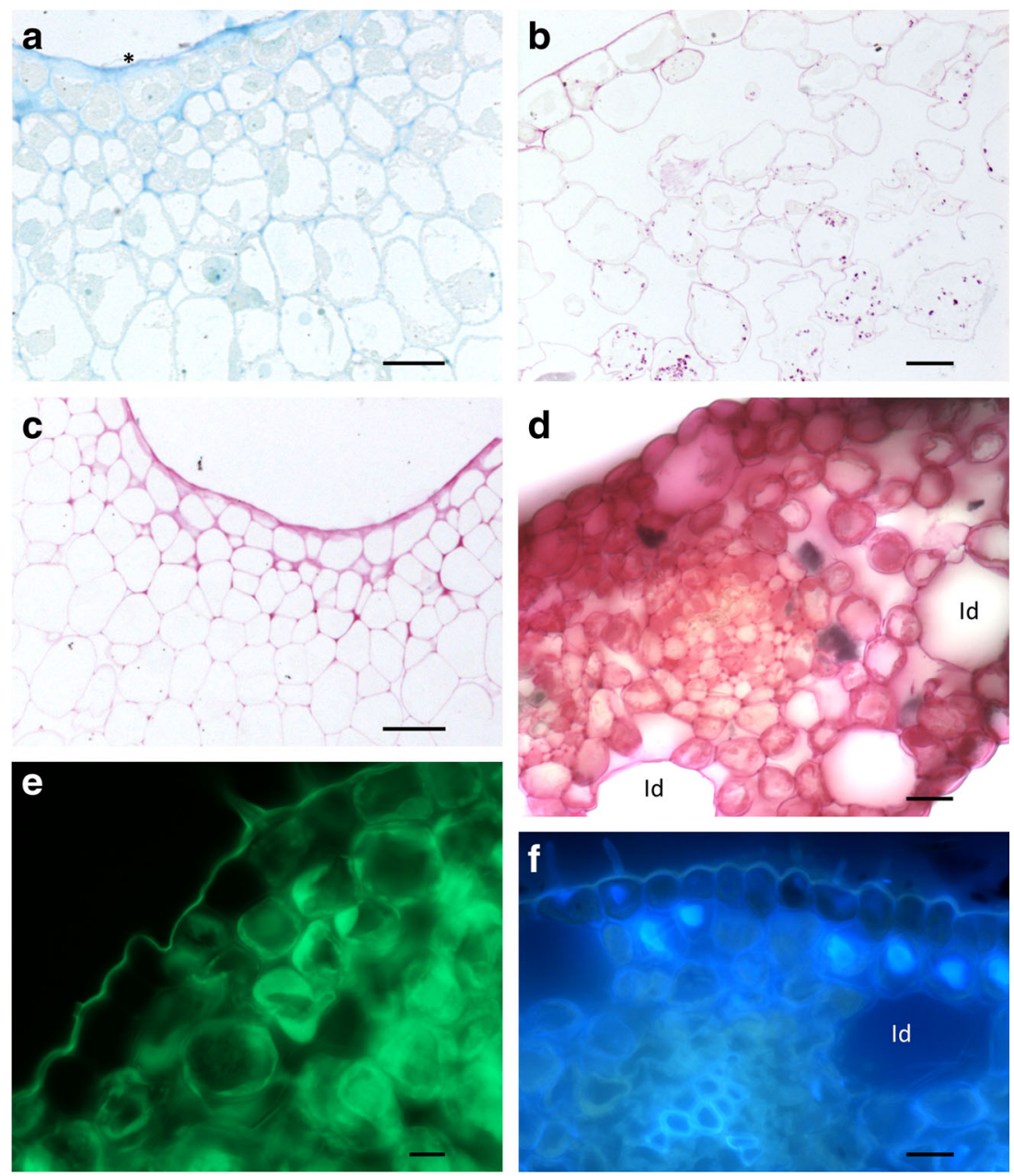

The surface secretion of $B$. saltatorium (based on SEM and TEM observations), like that of $B$. schinzianum (based on TEM), is heterogeneous and has a fibrous component. Unlike $B$. schinzianum, however, where the groove is lined with palisade-like cells, that of $B$. saltatorium is lined with more or less isodiametric cells, indicating, perhaps, that $B$. schinzianum displays a greater degree of secretory tissue organization. Remarkably, the cellulosic cell walls of the labellum of $B$. saltatorium have pronounced wall ingrowths that are absent from those of $B$. schinzianum. Cell wall protuberances are frequently present in various types of specialized plant secretory cells (transfer cells) engaged in high rates of solute transport (Offler et al. 2002). They have also been reported for the secretory tissues of some orchid flowers, such as elaiophore cells of Zygostates grandiflora (Lindl.) Mansf. (subtribe Oncidiinae; Ornithocephalus clade-Pacek et al. 2012), the epidermal cells of petals and the labellar groove of Bulbophyllum weberi Ames, whose cytoplasm and surface secretion contain lipids, proteins and pectin acids/mucilage (Kowalkowska et al. 2016), as well as the nectaries of Epipactis atropurpurea Raf. (Pais and Figueiredo 1994). In B. saltatorium, cell wall ingrowths were present both in cells that accumulate lipids, and in nectar-secreting cells, indicating that they are both involved in active secretion. Transport of secretion across the plasmalemma of secretory cells with cell wall ingrowths can occur either by eccrine secretion (Płachno et al. 2017) or by granulocrine secretion, where numerous secretory vesicles congregate near to and fuse with the plasmalemma (Nepi 2007). In B. saltatorium, the cytoplasm of nectary cells contained abundant vesicles derived from dictyosomes and ER (GERL or Golgi-Endoplasmic ReticulumLysosome system), and these fused with the plasmalemma. Small vesicles were also present in the periplasmic space, and cell wall ingrowths substantially enlarge the surface area of the plasmalemma. Numerous dictyosomes and dictyosome- or Golgi-derived vesicles are also a common feature of nectary cells, and occur in orchids, such as Platanthera Rich. (Stpiczyńska 1997) and Aeridinae (Stpiczyńska et al. 2011). In contrast to nectary cells, SER profiles predominate in cells that accumulate oils, and these are frequently located close to plastids, as those that occur in other lipid-producing cells, such as those of the elaiophores of Ornithophora radicans (Rchb.f.) Garay \& Pabst (Stpiczyńska and Davies 2008), Z. grandiflora (Pacek et al. 2012) and Lockhartia Hook. (Blanco et al. 2013). 
Fig. 4 Ultrastructure of oilsecreting cells, TEM. a Epidermal and subepidermal parenchyma cells. Large vacuole contains lipid; the presence of cell wall ingrowths in epidermal cell marked by arrows. Mitochondria occur in the parietal cytoplasm, scale bar $=5 \mu \mathrm{m}$. b Detail of epidermal cell with large vacuole and small vesicles, both containing lipids. Numerous ER profiles occur in the cytoplasm. Cell wall ingrowths are marked by arrows, scale bar $=2 \mu \mathrm{m}$. $\mathbf{c}$ Detail of secretory vesicles, some of which contain electron-dense bodies, scale bar $=1 \mu \mathrm{m}$. d Starchless plastids with dense stroma and internal membranes, scale bar $=1 \mu \mathrm{m}$. e Detail of parietal cytoplasm showing RER and plastid with plastoglobuli, scale bar $=0.5 \mu \mathrm{m}$. f Subepidermal parenchyma cells with plastids enclosing few, minute starch grains, scale bar $=2 \mu \mathrm{m}$. $L$ lipid, $P$ plastid

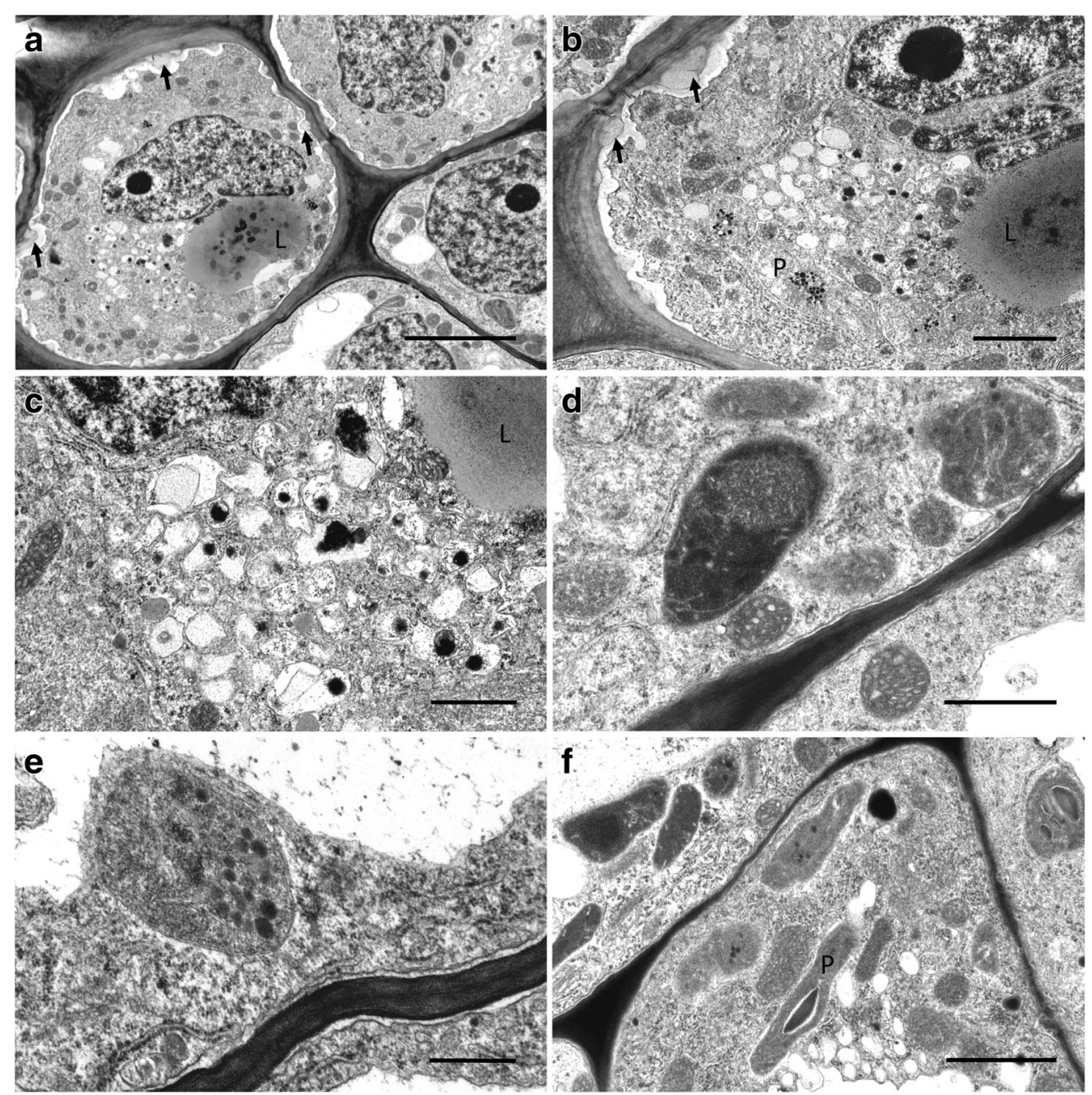

The cell walls of the secretory cells of $B$. saltatorium (particularly the periclinal cell walls in the region of the nectary) are thick and cellulosic, resembling those reported for the nectaries of other distantly related orchid taxa, such as Maxillaria Ruiz \& Pav. or Hexisea Lindl. (Stpiczyńska et al. 2004, 2005, respectively), several species of Aeridinae (Stpiczyńska et al. 2011) and Brassavola R. Br. (Stpiczyńska et al. 2010). Thick cellulosic cell walls in the nectary of some epiphytic orchids probably serve as a route for nectar transport onto the nectary surface. Since nectar is fundamentally an aqueous sugary solution, it may be transported within the polysaccharide matrix that constitutes the cell wall and is thus probably better protected against evaporation, especially since desiccation is a key stress factor for epiphytic plants. Therefore, the presence of thick cellulosic cell walls in unrelated epiphytic orchids is probably due to convergence. Despite this, the cuticle covering the thick outer cell walls of $B$. saltatorium is very thin, lacking the typical cuticular blisters and micro-channels seen in B. schinzianum (Stpiczyńska et al. 2015) and some other African and Asian species of Bulbophyllum investigated to date (Davies and Stpiczyńska 2014; Stpiczyńska et al. 2015; Kowalkowska et al. 2015, 2016). Therefore, by comparison, the thin cuticle of $B$. saltatorium appears to be more permeable than that of $B$. schinzianum, and this may aid nectar secretion.

Again, in both B. saltatorium and B. schinzianum, the underlying subepidermal cells are isodiametric and of similar size, and the parenchyma, which contains collateral vascular bundles and idioblasts with raphides, resembles aerial parenchyma or spongy mesophyll (Stpiczyńska et al. 2015, Stpiczynska et al. unpublished). The presence of aerial parenchyma in labella is not exclusively found in section Ptiloglossum, but it occurs also in other African, Asian and Neotropical Bulbophyllum species, and according to Teixeira et al. (2004), its presence aids movement of the labellum during pollination.

Three diverse kinds of trichome were present on the labellum of B. saltatorium: dense but delicate trichomes with smooth cell walls; long trichomes having irregularly sculptured cell walls, and massive capitate trichomes that accumulate large droplets of lipid. Moreover, unicellular trichomes and papillae coat the labellar callus. The first two classes of trichome, by increasing the surface area of the labellum, may also be involved in floral display and thus, the attraction of pollinators. 
Fig. 5 Ultrastructure of cells from nectary region, TEM. a Epidermal cells with thick, outer tangential wall and thin radial walls, interconnected by plasmodesmata. Surface secretion (nectar residue) marked by an asterisk, scale bar $=5 \mu \mathrm{m}$. $\mathbf{b}$ Detail of outer cell wall with thin cuticle and parietal cytoplasm. Note convoluted outline of plasmalemma and vesicles in periplasmic space; surface secretion marked by an asterisk, scale bar $=2 \mu \mathrm{m}$. c Parietal cytoplasm with numerous vesicles, ER and dictyosomes. Cell wall shows small ingrowths (arrows), scale bar $=2 \mu \mathrm{m}$. d Electron-dense parietal cytoplasm demonstrating the GERL system comprising dictyosomes or Golgi bodies, ER profiles and the numerous small vacuoles and secretory vesicles derived from it, scale bar $=1 \mu \mathrm{m}$. e Small vacuoles and vesicles containing osmiophilic material. Numerous dictyosomes occur in the parietal cytoplasm, scale bar $=1 \mu \mathrm{m}$. f Parietal cytoplasm with dictyosomes, ER profiles and secretory vesicles. Note cell wall ingrowths (arrows) with loose arrangement of cellulosic microfibrils, scale bar $=1 \mu \mathrm{m} . M b$ multivesicular body
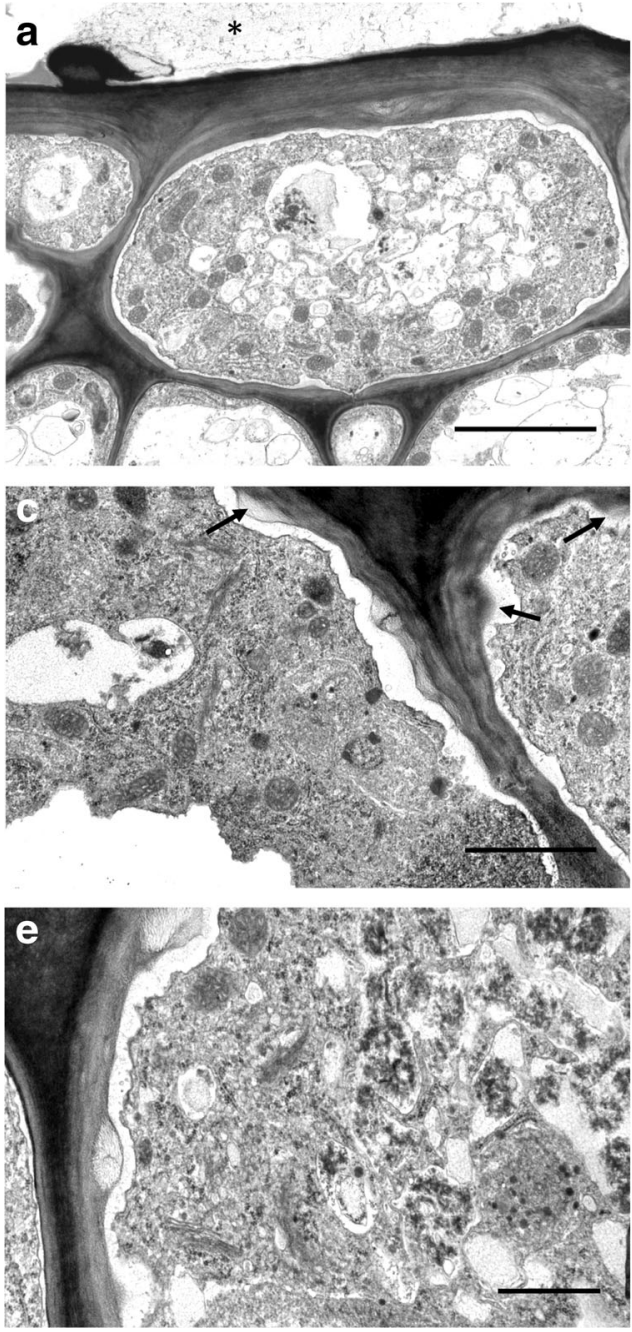

The massive trichomes of $B$. saltatorium are unusual in several ways. They contain large droplets of lipid, yet this material is absent from the labellar surface secretion. Therefore, it is possible that these cells are engaged in scent production since, in osmophores, the surface secretion (fragrance) tends to volatilize rapidly and thus disappear. Starch accumulation, however, which is typical of osmophore cells (Antoń et al. 2012, and references therein), was not observed here, but this is not surprising, since the starch may have been used as a source of energy for the highly metabolic process of fragrance production. Unlike the epidermal cells of many orchids that produce both fragrance and food-rewards, here, there is specialization resulting in division of labor coupled with structural modification, with trichomes producing lipid materials, whereas the cells lining the groove secrete nectar. Although the massive trichomes are laden with lipids, they differ from the elaiophore trichomes of orchids investigated so far (Pacek et al. 2012; Blanco et al. 2013) in that surface secretion is absent. To date, the production of a surface lipid-rich secretion by Bulbophyllum has been investigated for a number of species (Davies and Stpiczyńska 2014;
Stpiczyńska and Davies 2016, and references therein; Kowalkowska et al. 2015, 2016), but oleiferous trichomes were not present in any of these taxa. Alternatively, there also remains the possibility that the oil from such trichomes, in African species, might be gathered by specialized oilcollecting bees (van der Cingel 2001), such as species of Rediviva (Melittidae). However, at present, there is no evidence for this in Bulbophyllum.

\section{Conclusion}

In considering the species of Bulbophyllum investigated to date, it is possible to identify several main grades of labellar organization. These differ mainly in the type of receptacle involved in the secretion and presentation of food-rewards, ranging from a simple, shallow depression to a more highly organized, deep labellar groove that is able to secrete lipid-rich food-rewards, protein-laden mucilage or, as in B. schinzianum and $B$. saltatorium, nectar. Between these extremes occurs an intermediate grade comprising a shallow and wide concavity, 
as found in B. lobbii and B. macranthum (Stpiczyńska et al. unpublished). Bulbophyllum lobbii, which is fragrant, nectariferous and fly-pollinated, is considered by Christensen (1994) to have retained several features characteristic of bee-pollinated species.

The gross morphology and range of elaborate and highly specific pollination strategies is already well known for a small percentage of Bulbophyllum species, but with many still being discovered, and so many more remaining to be investigated fully, we can only speculate about the full diversity of the genus, not just about the floral morphology of its members, but also how they might differ at the micromorphological, anatomical, ultrastructural and biochemical levels, and the significance of each of these often slight and cryptic, but nonetheless very real differences with regard to pollinator selection and to the evolution and survival of these remarkable plants.

Acknowledgments Transmission electron microscopy studies were performed at the Laboratory of Electron Microscopy, Nencki Institute of Experimental Biology, Warsaw, Poland. TEM facilities were installed for the project and sponsored by the EU Structural Funds (SPO WWKP $1 / 1.4 .3 / 2 / 2005 / 102 / 222 / 562 / U)$. SEM studies were undertaken at the Scanning Microscopy Laboratory of the Department of Biological and Geological Sciences, Jagiellonian University in Kraków. LM microscope equipment used in this project was funded by the National Science Centre Poland, grant No 2014/15/B/NZ8/00210 to MS.

\section{Compliance with ethical standards}

Conflict of interest The authors declare that this work presents no conflict of interest.

Open Access This article is distributed under the terms of the Creative Commons Attribution 4.0 International License (http:// creativecommons.org/licenses/by/4.0/), which permits unrestricted use, distribution, and reproduction in any medium, provided you give appropriate credit to the original author(s) and the source, provide a link to the Creative Commons license, and indicate if changes were made.

\section{References}

Antoń S, Kamińska M, Stpiczyńska M (2012) Comparative structure of the osmophores in the flowers of Stanhopea graveolens Lindley and Cycnoches chlorochilon Klotzsch (Orchidaceae). Acta Agrobot 65: 11-22

Blanco M, Davies KL, Stpiczyńska M, Carlsward B, Ionta G, Gerlach G (2013) Floral elaiophores in Lockhartia Hook. (Orchidaceae: Oncidiinae): their distribution, diversity and anatomy. Ann Bot 112:1775-1791

Chen L-L, Gao J-Y (2011) Reproductive ecology of Bulbophyllum ambrosia (Orchidaceae). Chin J Plant Ecol 35:1202-1208

Christensen DE (1994) Fly pollination in the Orchidaceae. In: Arditti J (ed) Orchid biology: reviews and perspectives. VI John Wiley \& Sons, New York, pp 415-454

Davies KL, Stpiczyńska M (2008) The anatomical basis of floral, foodreward production in Orchidaceae. In: Texeira da Silva JA (ed)
Floriculture, ornamental and plant biotechnology. Global Science Books, UK, pp 392-407

Davies KL, Stpiczyńska M (2014) Labellar anatomy and secretion in Bulbophyllum Thouars (Orchidaceae: Bulbophyllinae) sect. Racemosae Benth. \& Hook. f. Ann Bot 114:889-911

Dressler RL (1990) The orchids - natural history and classification. Harvard University Press, London

Dressler RL (1993) Phylogeny and classification of the orchid family. Cambridge University Press, Cambridge

Fischer GA, Gravendeel B, Sieder A, Andriantiana J, Heiselmayer P, Cribb PJ, Smidt EDC, Samuel R, Kiehn M (2007) Evolution of resupination in malagasy species of Bulbophyllum (Orchidaceae). Mol Phylogenet Evol 45:358-376

Gravendeel B, Smithson A, Slik FJW, Schuiteman A (2004) Epiphytism and pollinator specialization. Drivers for orchid diversity? Philos Trans R Soc B 359:1523-1535

Humeau L, Micheneau C, Jacquemyn H, Gauvin-Bialecki A, Fournel J, Pailler T (2011) Sapromyiophily in the native orchid, Bulbophyllum variegatum, on Reunion (Mascarene Archipelago, Indian Ocean). J Trop Ecol 27:591-599

Jersáková J, Johnson SD, Kindlmann P (2006) Mechanisms and evolution of deceptive pollination in orchids. Biol Rev 81:219-235

Johansson D (1974) Ecology of vascular epiphytes in West African rain forest. Acta Phytogeograph Suec 59, Uppsala, pp 1-129

Jongejan P (1994) Specializations in ways of attracting insects for pollination in the genus Bulbophyllum. In: Proceedings of the 14th WOC, HMSO, Glasgow, pp 383-388

Kowalkowska AK, Kozieradzka-Kiszkurno M, Turzyński S (2015) Morphological, histological and ultrastructural features of osmophores and nectary of Bulbophyllum wendlandianum (Kraenzl.) Dammer (B. section Cirrhopetalum Lindl., Bulbophyllinae Schltr., Orchidaceae). Plant Syst Evol 301:609-622

Kowalkowska AK, Turzyński S, Kozieradzka-Kiszkurno M, Wiśniewska N (2016) Floral structure of two species of Bulbophyllum section Cirrhopetalum Lindl.: B. weberi Ames and B. cumingii (Lindl.) Rchb. f. (Bulbophyllinae Schltr., Orchidaceae). Protoplasma. https://doi.org/10.1007/s00709-016-1034-3

Liu Z-J, Chen L-J, Liu K-W, Li L-Q, Rao W-H (2010) A floral organ moving like a caterpillar for pollinating. J Syst Evol 48:102-108

Nepi M (2007) Nectary structure and ultrastructure. In: Nicolson S, Nepi M, Pacini E (eds) Nectaries and nectar. Springer, Dordrecht, pp 129 166

Nunes ELP, Smidt EC, Stützel T, Ike Coan A (2014) What do floral anatomy and micromorphology tell us about Neotropical Bulbophyllum section Didactyle (Orchidaceae: Bulbophyllinae)? Bot J Linn Soc 175:438-452

Nunes ELP, Smidt EC, Stützel T, Ike Coan A (2015) Comparative floral micromorphology and anatomy of species of Bulbophyllum section Napelli (Orchidaceae), a Neotropical section widely distributed in forest habitats. Bot J Linn Soc 177:378-394

Nunes EP, Emmerich Maldonado P, Smidt EC, Stützel T, Ike Coan A (2017) Floral micromorphology and anatomy and its systematic application to Neotropical Bulbophyllum section Micranthae (Orchidaceae). Bot J Linn Soc 183:294-315

Offler CE, David W, DW MC, Patrick JW, Talbot MJ (2002) Transfer cells: cells specialized for a special purpose. Annu Rev Plant Biol $54: 431-454$

Ong PT (2011) The pollination of Bulbophyllum patens. Orchid Rev 119: 146-149

Ong PT, Tan KH (2011) Fly pollination in four Malaysian species of Bulbophyllum (section Sestochilus) B. lasianthum, B.lobbii, B. subumbellatum and $B$. virescens. Malesian Orchid J 8:103-110

Ong PT, Tan KH (2012) Three species of Bulbophyllum section Racemosae pollinated by Drosophila flies. Malesian Orchid J 9: $45-50$ 
Ong PT, Hee AKW, Wee SL, Tan KH (2011) The attraction of flowers of Bulbophyllum (section Sestochilus) to Bactrocera fruit flies (Diptera: Tephritidae). Malesian Orchid J 8:93-102

Pacek A, Stpiczyńska M, Davies KL, Szymczak G (2012) Floral elaiophore structure in four representatives of the Ornithocephalus clade (Orchidaceae: Oncidiinae). Ann Bot 110:809-820

Pais MS, Figueiredo ACS (1994) Floral nectaries from Limodorum abortivum (L) Sw and Epipactis atropurpurea Rafin (Orchidaceae): ultrastructural changes in plastids during the secretory process. Apidologie 25:615-626

Płachno BJ, Stpiczyńska M, Krajewski Ł, Świątek P, Adamec L, Miranda VFO (2017) Flower palate structure of the aquatic bladderworts Utricularia bremii Heer and U. minor L. from section Utricularia (Lentibulariaceae). Protoplasma. https://doi.org/10.1007/s00709017-1097-9

Pohl F (1935) Zwei Bulbophyllum-Arten mit besonders bemerkenswert gebauten Gleit- und Klemfallenblumen. Beih Bot Zentralbl 53:501518

Porsch O (1905) Beiträge zur "histologischen" Blütenbiologie I. Österr Bot Z 55:253-260

Pridgeon AM, Cribb PJ, Chase MW, Rasmussen FN (2014) Genera Orchidacearum Vol 6; Epidendroideae (Part 3). Oxford University Press, Oxford

Reynolds ES (1963) The use of lead citrate at high $\mathrm{pH}$ as an electronopaque stain for electron microscopy. J Cell Biol 17:208-212

Ruzin SE (1999) Plant microtechnique and microscopy. Oxford University Press, New York

Stewart T, Biteau JP, Cawoy V, Droissart V (2014) Taxonomy of Atlantic Central African orchids 3. A new species of Bulbophyllum Thouars (Orchidaceae) from the Monts de Cristal, Gabon. Phytotaxa 77:2634

Stpiczyńska M (1997) The structure of nectary of Platanthera bifolia L. Orchidaceae. Acta Soc Bot Pol 66:5-11

Stpiczyńska M, Davies KL (2008) Elaiophore structure and oil secretion in flowers of Oncidium trulliferum Lindl. and Ornithophora radicans (Rchb.f) Garay \&Pabst (Oncidiinae: Orchidaceae). Ann Bot 101:375-384

Stpiczyńska M, Davies KL (2016) Evidence for the dual role of floral secretory cells in Bulbophyllum. Acta Biol Cracov Bot 58:57-69

Stpiczyńska M, Davies KL, Gregg A (2004) Nectary structure and nectar secretion in Maxillaria coccinea (Jacq.) L.O. Williams ex Hodge (Orchidaceae). Ann Bot 93:87-95

Stpiczyńska M, Davies KL, Gregg A (2005) Comparative account of nectary structure in Hexisea imbricata Lindl. Rchb.f. (Orchidaceae). Ann Bot 95:749-756

Stpiczyńska M, Davies KL, Kamińska M (2010) Structure of the cuniculus nectary in Brassavola flagellaris Barb. Rodr (Laeliinae Benth.,Orchidaceae). Acta Agrobot 63:3-10

Stpiczyńska M, Davies KL, Kamińska M (2011) Comparative anatomy of the nectary spur in selected species of Aeridinae (Orchidaceae). Ann Bot 107:327-345

Stpiczyńska M, Davies KL, Kamińska M (2015) Diverse labellar secretions in African Bulbophyllum (Orchidaceae: Bulbophyllinae) sections Ptiloglossum, Oreonastes and Megaclinium. Bot J Linn Soc 179:266-287

Tan KH, Nishida R (2000) Mutual reproductive benefits between a wild orchid, Bulbophyllum patens, and Bactrocera fruit flies via a floral synomone. J Chem Ecol 26:533-546

Tan KH, Nishida R (2005) Synomone or kairomone? Bulbophyllum apterum flower releases raspberry ketone to attract Bactrocera fruit flies during pollination. J Chem Ecol 31:509-519

Tan KH, Nishida R, Toong YC (2002) Floral synomone of a wild orchid, Bulbophyllum cheiri, lures Bactrocera fruit flies for pollination. J Chem Ecol 28:1161-1172

Teixeira SP, Borba EL, Semir J (2004) Lip anatomy and its implications for the pollination mechanisms of Bulbophyllum species (Orchidaceae). Ann Bot 93:499-505

van der Cingel NA (2001) An atlas of orchid pollination-America, Africa, Asia and Australia. A.A. Balkema, Rotterdam 